\title{
Article \\ Satellite-Derived Protein Concentration of Phytoplankton in the Southwestern East/Japan Sea
}

\author{
Hyeonji Bae ${ }^{1}$, Dabin Lee ${ }^{1}$, Jae Joong Kang ${ }^{1}{ }^{\mathbb{D}}$, Jae Hyung Lee ${ }^{1}$, Naeun Jo ${ }^{1} \mathbb{D}$, Kwanwoo Kim ${ }^{1}$, Hyo Keun Jang ${ }^{1}$, \\ Myung Joon Kim ${ }^{1}$, Yejin Kim ${ }^{1}$ (D), Jae-Il Kwon ${ }^{2}$ and Sang Heon Lee ${ }^{1, * \mathbb{D}}$
}

1 Department of Oceanography, Pusan National University, Geumjeong-gu, Busan 46241, Korea; hjbae0427@gmail.com (H.B.); 1db1370@pusan.ac.kr (D.L.); jaejung@pusan.ac.kr (J.J.K.); tlyljh78@pusan.ac.kr (J.H.L.); nadan213@pusan.ac.kr (N.J.); goanwoo7@pusan.ac.kr (K.K.); janghk@pusan.ac.kr (H.K.J.); lion911231@naver.com (M.J.K.); yejini@pusan.ac.kr (Y.K.)

2 Marine Disaster Research Center, KIOST, Busan 49111, Korea; jikwon@kiost.ac.kr

* Correspondence: sanglee@pusan.ac.kr; Tel.: +82-51-510-2256

Citation: Bae, H.; Lee, D.; Kang, J.J.; Lee, J.H.; Jo, N.; Kim, K.; Jang, H.K.; Kim, M.J.; Kim, Y.; Kwon, J.-I.; et al. Satellite-Derived Protein Concentration of Phytoplankton in the Southwestern East/Japan Sea. J. Mar. Sci. Eng. 2021, 9, 189. https://doi.org/10.3390/ jmse9020189

Academic Editor: Carmela Caroppo Received: 15 January 2021

Accepted: 9 February 2021

Published: 11 February 2021

Publisher's Note: MDPI stays neutral with regard to jurisdictional claims in published maps and institutional affiliations.

Copyright: (c) 2021 by the authors. Licensee MDPI, Basel, Switzerland. This article is an open access article distributed under the terms and conditions of the Creative Commons Attribution (CC BY) license (https:// creativecommons.org/licenses/by/ $4.0 /)$.

\begin{abstract}
The cellular macromolecular contents and energy value of phytoplankton as primary food source determine the growth of higher trophic levels, affecting the balance and sustainability of oceanic food webs. Especially, proteins are more directly linked with basic functions of phytoplankton biosynthesis and cell division and transferred through the food chains. In recent years, the East/Japan Sea (EJS) has been changed dramatically in environmental conditions, such as physical and chemical characteristics, as well as biological properties. Therefore, developing an algorithm to estimate the protein concentration of phytoplankton and monitor their spatiotemporal variations on a broad scale would be invaluable. To derive the protein concentration of phytoplankton in EJS, the new regional algorithm was developed by using multiple linear regression analyses based on field-measured data which were obtained from 2012 to 2018 in the southwestern EJS. The major factors for the protein concentration were identified as chlorophyll- $a$ (Chl-a) and sea surface nitrate (SSN) in the southwestern EJS. The coefficient of determination $\left(\mathrm{r}^{2}\right)$ between field-measured and algorithmderived protein concentrations was 0.55 , which is rather low but reliable. The satellite-derived estimation generally follows the 1:1 line with the field-measured data, with Pearson's correlation coefficient, which was 0.40 ( $p$-value $<0.01, \mathrm{n}=135)$. No remarkable trend in the long-term annual protein concentration of phytoplankton was found in the study area during our observation period. However, some seasonal difference was observed in winter protein concentration between the 2003-2005 and 2017-2019 periods. The algorithm is developed for the regional East/Japan Sea (EJS) and could contribute to long-term monitoring for climate-associated ecosystem changes. For a better understanding of spatiotemporal variation in the protein concentration of phytoplankton in the EJS, this algorithm should be further improved with continuous field surveys.
\end{abstract}

Keywords: protein concentration of phytoplankton; chlorophyll- $a$; nitrate; phytoplankton; ocean color; East/Japan Sea

\section{Introduction}

The southern area of the East Japan Sea (EJS) is well known for high primary productivity with various physical processes such as coastal upwelling, eddies, and sub-polar fronts [1-4]. These diverse physical processes sustain high primary productivity in the EJS. Recently, various changes in physical-chemical, and biological properties have been reported in the EJS. Particularly, a dramatic change in the vertical distribution of the chemical properties and sea surface temperature of winter and spring was observed in the southern EJS during the last few decades [4-7]. Phytoplankton physiology is dynamic and highly responsive to environmental conditions. Phytoplankton acclimates to changing environmental conditions by a complex reallocation of carbon and energy through metabolic pathways to optimize growth [8]. Indeed, some biological changes especially in 
phytoplankton responding to climate change have been studied locally and temporally by field research and remote-sensed ocean color data in the EJS. The timings and magnitudes of spring and fall blooms have been started earlier and weaker in the EJS [9,10]. Joo et al. [4] found a decreasing trend in the annual primary production for 1.3\% each year in the EJS from 2003 to 2012 using MODIS-aqua satellite data. The species composition and the macromolecular composition of phytoplankton, which in turn are closely related to the variation of zooplankton biomass, can be adjusted to the changing environment $[6,10]$. Subsequently, these changes in phytoplankton could induce considerable alternations of the upper trophic levels. Jung et al. [11] reported the habitat changes and the decrease of fish caught have been observed in the EJS. Consequently, their biomass, species compositions, and the cellular macromolecular contents of phytoplankton could strongly impact the trophic balance within a marine ecosystem $[12,13]$.

The macromolecular composition (e.g., proteins, carbohydrates, and lipids) of phytoplankton could provide significant information for their physiological and qualitative status. When environmental conditions are appropriate, primary production and growth rates of phytoplankton increase. A high carbon allocation into proteins is known as an indicator of a physiologically healthy condition of phytoplankton [14,15]. Proteins are more directly linked with basic functions of biosynthesis and cell division [16] and tend to be conserved through the food chains and harsh conditions such as low irradiance or low nutrients conditions on account of the high energetic cost of their synthesis $[17,18]$. Proteins are nitrogen-based substances and are produced through nitrogen intake $[19,20]$. Nitrogen is one of the main nutrients that can directly limit phytoplankton production in the ocean [21,22]. Normally, proteins provide nitrogen-sufficient food and essential amino acids that are not produced in the consumer's body [23,24].

Over the past 20 years, starting with monitoring chlorophyll-a (Chl-a) concentration in 1997, various satellite-based approaches such as phytoplankton function types (PFTs) or phytoplankton size classes (PSCs), and primary production of phytoplankton have been developed and expanded for phytoplankton ecology from remote sensing ocean color data $[4,25-27]$. Since the protein concentration of phytoplankton has been conducted from discrete field measurements, no detailed information on the temporal and spatial variations in the protein concentration of phytoplankton is currently available in the EJS. Given that field measurements are often infrequent and inadequate for monitoring over large spatial scales, satellite-based estimates over large spatial and long-time scales would be invaluable for better understanding ecological conditions of phytoplankton and thus marine ecosystems responding to current/ongoing environmental changes. In this study, an empirical algorithm for the protein concentration of phytoplankton based on the field measurement data from various cruises was organized for the southwestern EJS to detect its temporal and spatial variation using the ocean-color data from satellite remote-sensing. The regional algorithm was developed by selecting major environmental factors through multiple linear regression analysis based on field-measured data from 2012 to 2018 in the southwestern EJS. The main objectives of this study were to develop a regional algorithm for protein concentration for phytoplankton based on field-measured data, to characterize the temporal and spatial distribution of protein concentration using ocean color data, and to find the main controlling factors in the southwestern EJS during the observation period from 2003 to 2019.

\section{Materials and Methods}

\subsection{Study Area and Sampling}

The field-measured total Chl-a, particulate organic carbon (POC), sea surface nitrate concentration (SSN), sea surface temperature (SST), and protein concentrations of phytoplankton in the southwestern EJS were obtained from various research cruises from 2012 to 2018. The total number of field-measured protein concentrations was 205 stations, which are plotted in Figure 1, and the detailed information is summarized in Table 1. 

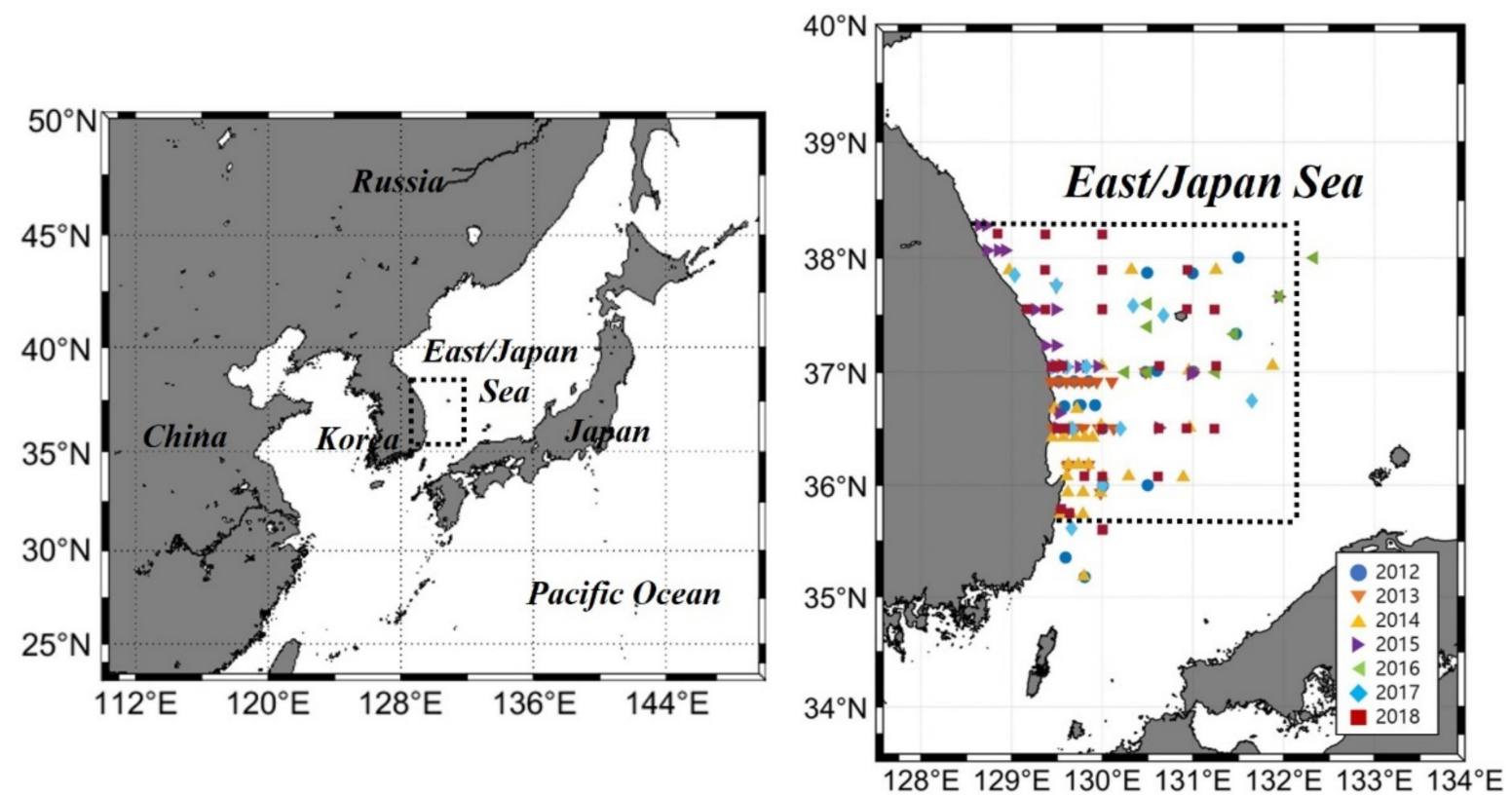

Figure 1. Field measurement stations in the East/Japan Sea (EJS) from 2012 to 2018. Dotted black lines indicate the domain for the study area.

Table 1. Information for the field-measured data in the East/Japan Sea (EJS): sampling date, number of stations, and geographic position.

\begin{tabular}{|c|c|c|c|c|}
\hline Year & Month & Number of Stations & Longitude Range & Latitude Range \\
\hline \multirow{3}{*}{2012} & March & 8 & \multirow{3}{*}{$129.5^{\circ} \mathrm{E}-131.5^{\circ} \mathrm{E}$} & \multirow{3}{*}{$35.2^{\circ} \mathrm{N}-38^{\circ} \mathrm{N}$} \\
\hline & July & 6 & & \\
\hline & October & 6 & & \\
\hline \multirow{5}{*}{2013} & January & 1 & \multirow{5}{*}{$129.4^{\circ} \mathrm{E}-131^{\circ} \mathrm{E}$} & \multirow{5}{*}{$35.7^{\circ} \mathrm{N}-37.7^{\circ} \mathrm{N}$} \\
\hline & May & 5 & & \\
\hline & June & 5 & & \\
\hline & August & 12 & & \\
\hline & September & 3 & & \\
\hline \multirow{8}{*}{2014} & April & 4 & \multirow{8}{*}{$128.9^{\circ} \mathrm{E}-131.9^{\circ} \mathrm{E}$} & \multirow{8}{*}{$35.2^{\circ} \mathrm{N}-37.9^{\circ} \mathrm{N}$} \\
\hline & May & 4 & & \\
\hline & June & 11 & & \\
\hline & July & 6 & & \\
\hline & August & 7 & & \\
\hline & September & 6 & & \\
\hline & October & 9 & & \\
\hline & November & 20 & & \\
\hline \multirow{4}{*}{2015} & May & 13 & \multirow{4}{*}{$128.6^{\circ} \mathrm{E}-131.9^{\circ} \mathrm{E}$} & \multirow{4}{*}{$36.5^{\circ} \mathrm{N}-38.3^{\circ} \mathrm{N}$} \\
\hline & June & 5 & & \\
\hline & July & 10 & & \\
\hline & November & 5 & & \\
\hline 2016 & April & 8 & $130.3^{\circ} \mathrm{E}-132.3^{\circ} \mathrm{E}$ & $37^{\circ} \mathrm{N}-38^{\circ} \mathrm{N}$ \\
\hline \multirow{2}{*}{2017} & May & 9 & \multirow{2}{*}{$129^{\circ} \mathrm{E}-131.65^{\circ} \mathrm{E}$} & \multirow{2}{*}{$35.6^{\circ} \mathrm{N}-37.9^{\circ} \mathrm{N}$} \\
\hline & June & 3 & & \\
\hline \multirow{4}{*}{2018} & $\begin{array}{c}\text { February- } \\
\text { March }\end{array}$ & 9 & \multirow{4}{*}{$128.8^{\circ} \mathrm{E}-131.3^{\circ} \mathrm{E}$} & \multirow{4}{*}{$35.6^{\circ} \mathrm{N}-38.2^{\circ} \mathrm{N}$} \\
\hline & April & 10 & & \\
\hline & August & 10 & & \\
\hline & October & 10 & & \\
\hline
\end{tabular}


Water samples for the total Chl-a, POC, SSN, SST, and protein concentration for phytoplankton were sampled from the surface layer using a rosette sampler with Niskin bottles. Samples for the total Chl-a were filtered through $25 \mathrm{~mm}$ GF/F filters (Whatman) and extracted in $90 \%$ acetone at $4{ }^{\circ} \mathrm{C}$ for $24 \mathrm{~h}$, and the concentrations were measured using a 10-AU fluorometer (Turner Designs). POC was filtered on $25 \mathrm{~mm}$ GF / F filters and frozen immediately and measured for mass spectrometric analysis at the stable isotope facility of the University of Alaska Fairbanks, USA. Water samples for SSN were filtered through a $47 \mathrm{~mm}$ GF /F (Whatman), and filtered water samples $(45 \mathrm{~mL})$ were frozen at $-80{ }^{\circ} \mathrm{C}$ in a $50 \mathrm{~mL}$ conical tube for later analysis. The concentrations of SSN were analyzed using an automated nutrient analyzer (Quaatro, Seal Analytical, Germany) from the manufacturer's instruction in the National Institute of Fisheries Science (NIFS). SST was measured at each station and observation time with a Conductivity-Temperature-Depth Sensors (CTD). For the protein concentration of phytoplankton, the method of Lowry et al. [28] was used to measure the concentration [29]. Water samples were filtered through $47 \mathrm{~mm} \mathrm{GF/F}$ filters (Whatman) and frozen at $-80{ }^{\circ} \mathrm{C}$ until spectrometric analysis in the laboratory. The samples for the protein concentrations that were collected on filters were sliced and put into amber vials with Deionized water $(1 \mathrm{~mL})$ and alkaline copper solution $(5 \mathrm{~mL})$, and then ultra-sonicated for $20 \mathrm{~min}$. The solutions were mixed with a vortex mixer and kept at room temperature for $10 \mathrm{~min}$. Then, diluted Folin-Ciocalteu phenol reagent $(0.5 \mathrm{~mL})$ was added into each solution and kept at room temperature for $1 \mathrm{~h} 30 \mathrm{~min}$. After this process, the samples were transferred to borosilicate glass tubes centrifuged at $3000 \mathrm{rpm}$ for $10 \mathrm{~min}$, and the supernatant for the solution was detected for the protein concentration with a UV spectrophotometer at $750 \mathrm{~nm}$. The protein concentrations were calculated from calibration curves with a protein standard solution $\left(2 \mathrm{mg} \cdot \mathrm{mL}^{-1}\right.$, SIGMA).

\subsection{Development of the Protein Concentration Algorithm}

The protein concentration algorithm for the southwestern EJS was empirically derived with our field-measured data. We used a total of 205 field-measured data for developing the regional algorithm for the protein concentration of phytoplankton. To identify how variables influence the protein concentration of phytoplankton, multilinear regression models were applied to the data using a stepwise variable section as follows:

$$
Y=\beta_{0}+\beta_{1} P_{1}+\beta_{2} P_{2}+\cdots+\beta_{n} P_{n}+\varepsilon
$$

where $Y$ is the dependent variable, which is the protein concentration of phytoplankton estimating from the independent variables, $P_{1} \cdots P_{n}$, which is Chl-a and SSN. The parameter $\beta_{0}$ is constant. $\beta_{1} \cdots \beta_{n}$ are the regression coefficients for the predictors, and $\varepsilon$ is the error term. Predictors in a multilinear regression model need to be independent of each other to yield correct results. Therefore, principal component analysis (PCA) was implemented by SPSS software version 12.0 program (SPSS Inc, Chicago, IL, USA) to find correlations and independence among the variables. Physical, chemical, and biological variables (SST, SSN, Chl-a, and POC) were applied to PCA. In addition, the stepwise variable selection method with F-test was used to confirm the predictors. The protein concentration of phytoplankton algorithm as a function of Chl-a and SSN is as follows:

$$
\mathrm{PRT}=51.344+23.404 \times \mathrm{Chl}-\mathrm{a}-6.755 \times \mathrm{SSN}
$$

\subsection{Satellite Ocean Color Data}

To estimate the satellite-derived protein concentration based on the protein-estimating algorithm, ocean color data were obtained from MODIS (Moderate Resolution Imaging Spectrometer)-Aqua by the OBPC (Ocean Biology Processing Group at NASA Goddard Space Flight Center; https:/ / oceandata.sci.gsfc.nasa.gov/MODIS-Aqua/). We used the monthly level-3 datasets including Chl-a and SST covering the EJS from January 2003 to December 2019 at $4 \mathrm{~km}$ of spatial resolution. A regional Sea Surface Nitrate (SSN) was calculated based on Chl-a and SST from ocean color data with the regional SSN 
algorithm [30]. Mixed layer depths of the EJS were obtained from ECCO (Estimating the Circulation and Climate of the Ocean; https:/ / www.ecco-group.org/).

\section{Result}

\subsection{Physical and Chemical Conditions in the EJS}

From field studies from 2012 to 2018, a total of 205 data were obtained mainly from February to November (Table 1). During the overall research period, Chl-a, SSN, SST and PRT ranged from 0.05 to $10.4 \mu \mathrm{g} \cdot \mathrm{L}^{-1}$ (mean \pm S.D. $=1.23 \pm 1.67 \mu \mathrm{g} \cdot \mathrm{L}^{-1}$ ), 0.03 to $8.37 \mu \mathrm{M}$ (mean \pm S.D. $=2.25 \pm 2.13 \mu \mathrm{M}), 7.6$ to $28.7^{\circ} \mathrm{C}\left(\right.$ mean \pm S.D. $\left.=19.6 \pm 4.6^{\circ} \mathrm{C}\right)$, and 3.2 to $454.2 \mu \mathrm{g} \cdot \mathrm{L}^{-1}$ (mean \pm S.D. $=76.5 \pm 64.2 \mu \mathrm{g} \cdot \mathrm{L}^{-1}$ ), respectively. Distinct seasonal variations were detected precisely in every environmental condition (Figure 2). The concentrations of Chl-a were high in spring and lower in summer (Figure 2a). The concentrations of SSN were high in winter and lower in other seasons (Figure 2b). SST was high in summer and autumn (Figure 2c). The protein concentration of phytoplankton was high in spring and autumn, lower in summer and winter (Figure 2d).

a)

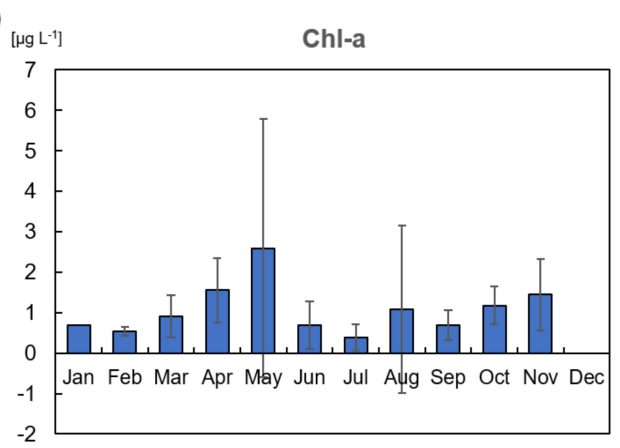

c)

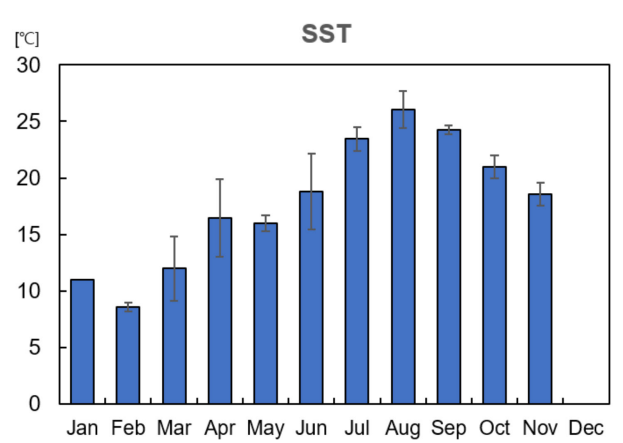

b)

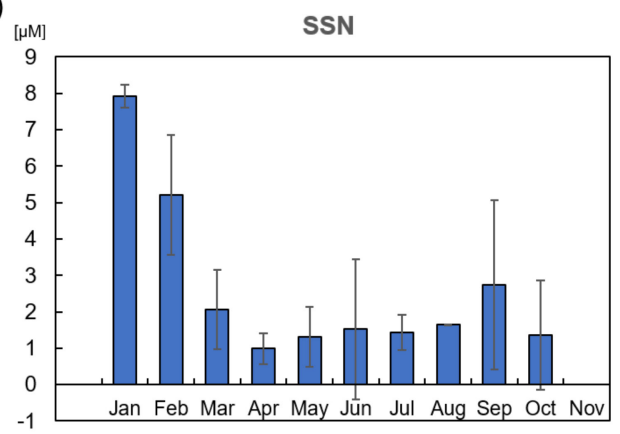

d) $)_{[\mu g ~ L-1]}$

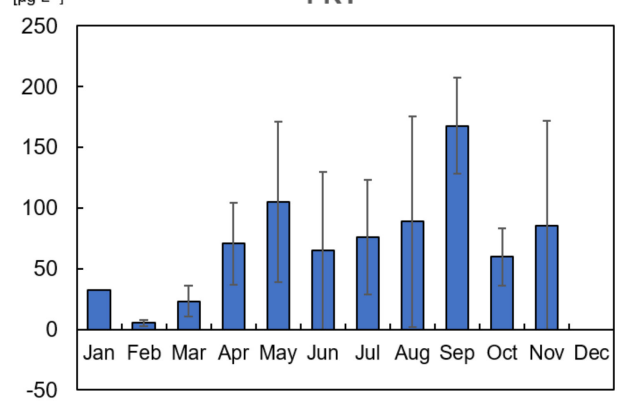

Figure 2. The monthly distribution of the field data, (a) is chlorophyll-a, (b) is sea surface nitrate, (c) is sea surface temperature, and $(\mathbf{d})$ is protein concentration of phytoplankton.

\subsection{Derivation of Protein Concentration of Phytoplankton Algorithm in the EJS}

Field-measured protein concentrations of phytoplankton were collected from several cruises from 2012 to 2018 for a regional protein algorithm in the EJS. Field-measured protein concentrations of phytoplankton ranged from $3.2 \mu \mathrm{g} \cdot \mathrm{L}^{-1}$ to $454.2 \mu \mathrm{g} \cdot \mathrm{L}^{-1}$ with an average of $74.9 \mu \mathrm{g} \cdot \mathrm{L}^{-1}$ (S.D. $= \pm 62.8 \mu \mathrm{g} \cdot \mathrm{L}^{-1}$ ). To derive a regional algorithm for the phytoplankton protein concentration we used two variables which are Chl-a and SSN from field-measured data. The coefficient of determination $\left(\mathrm{r}^{2}\right)$ between field-measured and algorithm-derived protein concentrations based on Chl-a concentrations was 0.25 (Figure 3a). An additional parameter of SSN induced a considerable increase in the $\mathrm{r}^{2}$ to 0.55 (Figure $3 \mathrm{~b}$ and Table 2) indicating that nutrients would be an important contributor to control the protein concentration of phytoplankton. As a result of stepwise analysis of multilinear regression, SST as an additional factor was not selected because it does not significantly affect the protein concentration. Moreover, multilinear regression is 
based on the assumption of independence between variables; supplementary variables for POC that were not independent among the variables by the PCA were excluded in our algorithm analysis. The satellite-derived SSN concentration is calculated by SST and Chl-a, according to Joo et al. [30] algorithm. which is primarily controlled by SST. The Pearson's correlation coefficient between Chl-a and SSN was 0.28 ( $p$-value > 0.05), which suggests that they are independent.

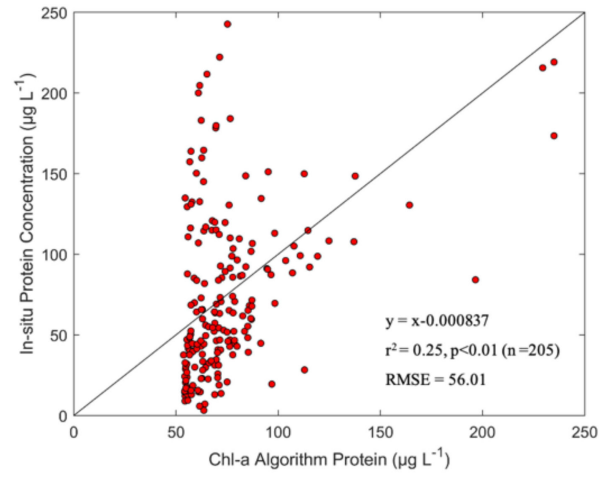

(a)

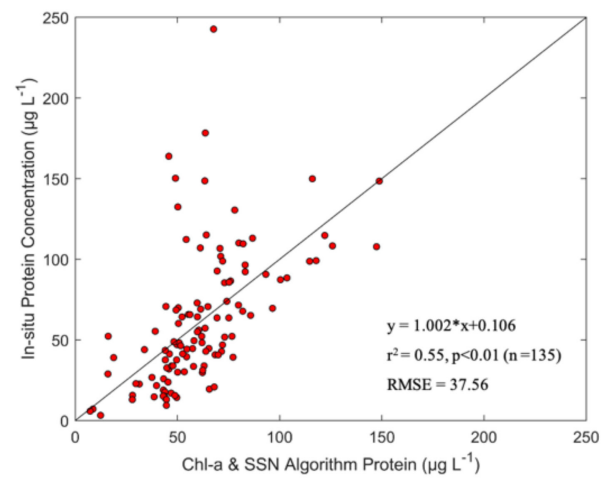

(b)

Figure 3. The validation of a regional algorithm for the phytoplankton protein concentration of phytoplankton. The linear relationship between field-measured and algorithm-derived protein concentrations of phytoplankton is (a) based on chlorophyll-a concentrations and (b) based on chlorophyll-a and sea surface nitrate concentrations. Black solid lines represent the 1:1 line.

Table 2. The result of multilinear regression analysis for the protein concentration of phytoplankton in the EJS.

\begin{tabular}{cccccccc}
\hline $\begin{array}{c}\text { Included } \\
\text { Independent } \\
\text { Variables }\end{array}$ & $\begin{array}{c}\text { Regression } \\
\text { Coefficient } \\
\left.\mathbf{( b}_{\mathbf{k}}\right)\end{array}$ & $\begin{array}{c}\text { Standard } \\
\text { Error of } \mathbf{b}_{\mathbf{k}}\end{array}$ & $\begin{array}{c}\text { Standardized } \\
\text { Regression } \\
\text { Coefficient }\end{array}$ & $\boldsymbol{t}$-Test & $\boldsymbol{p}$-Value & VIF & $\mathbf{R}^{\mathbf{2}} \mathbf{( \% )}$ \\
\hline Constant & 51.44 & 5.844 & - & 8.802 & $0.000^{* *}$ & \\
Chl-a & 23.404 & 2.142 & 0.675 & 10.926 & $0.000^{* *}$ & 1.008 & 48.7 \\
SSN & -6.755 & 1.620 & -0.258 & -4.169 & $0.000^{* *}$ & 1.008 & 55.3 \\
\hline
\end{tabular}

${ }^{*} p<0.05,{ }^{* *} p<0.01$.

\subsection{Comparison of Algorithm-Derived Concentrations of Protein with Field-Measured Data}

To estimate the protein concentration of phytoplankton by satellite, monthly Chl-a concentration and SST data from MODIS-aqua L3 were extracted from the same location, matched with the field-measured stations. The algorithm-derived estimation from MODISaqua retrieved-data and the field-measured data generally follow the 1:1 line; significant Pearson's correlation coefficient was 0.40 and the $p$-value was $<0.01$ with $n=135$ (Figure 4). Most of the satellite-derived protein concentrations were plotted in the $95 \%$ prediction bounds. The root mean squared error (RMSE) and bias of the estimation were 49.9 and $15.7 \mu \mathrm{g} \cdot \mathrm{L}^{-1}$. Three more metrics were calculated to verify the validity of the model outputs compared with the field data [31]. The median satellite-to-field ratio (median ratio) close to 1 implies how well the algorithm-matched and the field-measured data fit together. The median of the relative-percent differences (median RPD) indicates between the satellite and the field-measured distribution medians to quantify relative biases, and the semi-interquartile percent differences (SIQ-PD) quantify relative differences in distribution widths. These algorithms of median ratio, median PRD, and SIQ-PD are 1.07, 6.98, and -59.4 , respectively. Through these metrics, our algorithm generally matched the field-measured protein concentrations, and the variability of the satellite-derived protein concentration was lower than the field-measured data (Figure 5a). The algorithm-derived estimation and the field- 
measured data with seasonal distribution of the protein concentration showed a more precise similar tendency (Figure 5b).

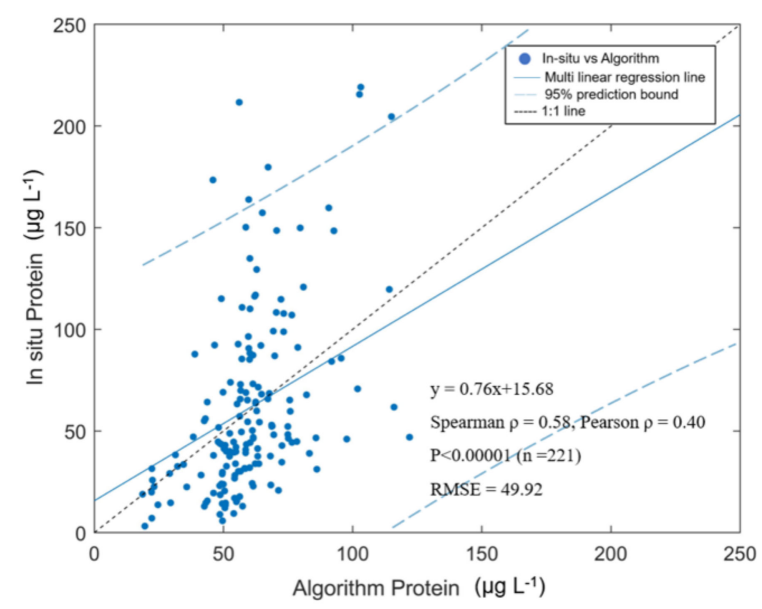

Figure 4. Linear relationship between the protein concentration of phytoplankton derived by the algorithm and field-measured data.

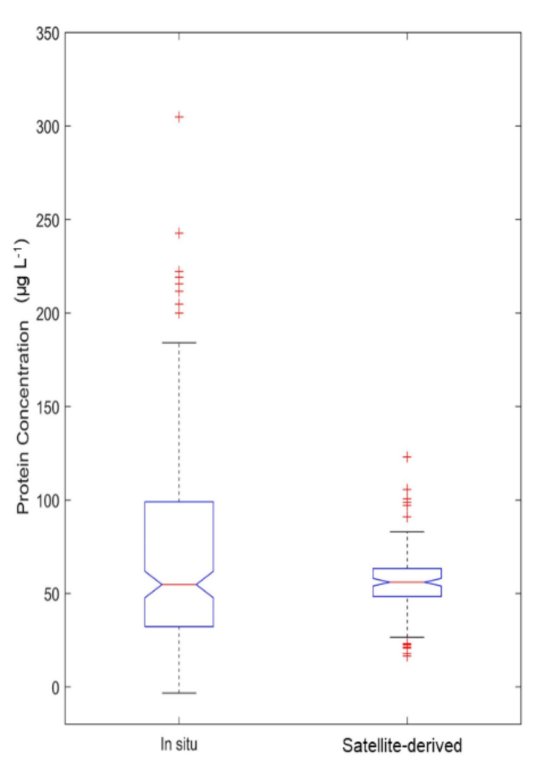

(a)

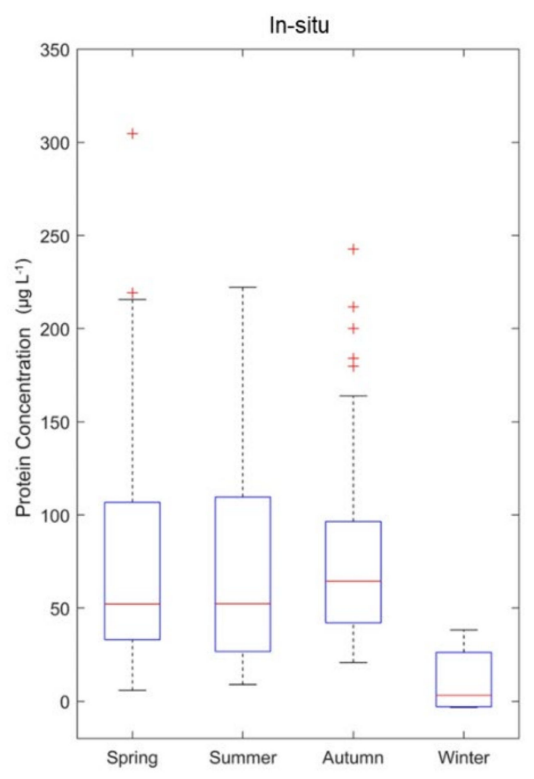

(b)

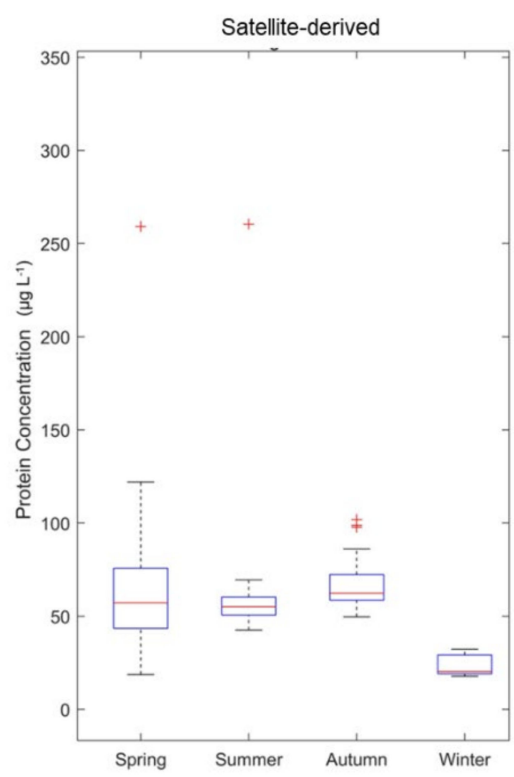

Figure 5. Boxplots comparing the field-measurements with satellite-derived based on the regional algorithm with total data (a) and seasonal distribution (b).

\subsection{Spatial and Seasonal Variation in MODIS-Derived Protein Concentration}

Based on our new regional algorithm, the MODIS-derived climatological monthly protein concentration pattern of phytoplankton was produced in the southwestern EJS from January 2003 to December 2019. The monthly protein concentration of phytoplankton based on monthly climatology images of the MODIS-derived protein concentration (Figure 6) ranged from $26.6 \mu \mathrm{g} \cdot \mathrm{L}^{-1}$ (February 2018) to $138.2 \mu \mathrm{g} \cdot \mathrm{L}^{-1}$ (April 2008) with an average of $54.1 \mu \mathrm{g} \cdot \mathrm{L}^{-1}$ (S.D. $\left.= \pm 14.3 \mu \mathrm{g} \cdot \mathrm{L}^{-1}\right)$ from 2003 to 2019. 

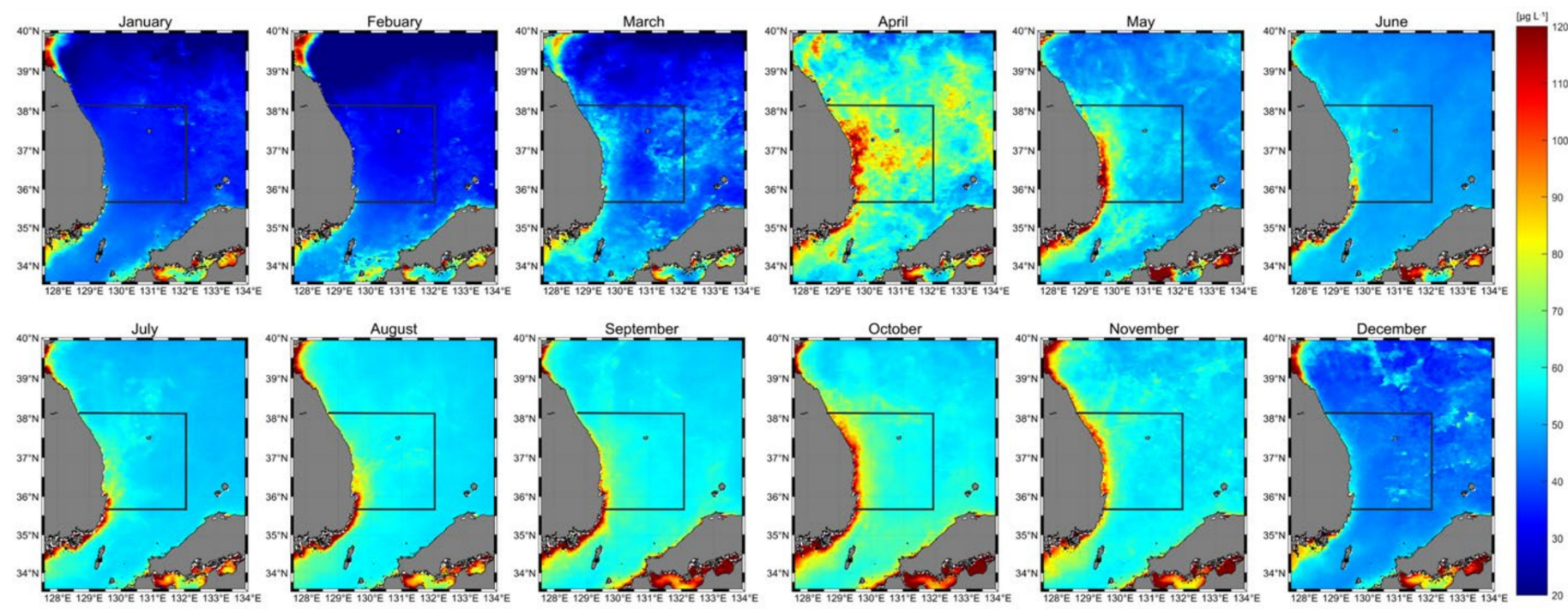

Figure 6. Climatological monthly averaged distribution of protein concentration of phytoplankton based on the MODISderived protein concentration from 2003 to 2019 in the EJS.

Generally, the protein concentration was lowest in the winter and early spring (January to March) in the study area. Around the Korean coastal regions, the concentration was relatively higher than offshore. The protein concentration peaked in April over the southwestern EJS. From May to June, the concentration slightly decreased and did not drop markedly like Chl-a or SSN concentration. During the period, a relatively higher protein concentration was continuously observed along the southwestern coastal region. From July to October the high concentrations were observed in the south of the coast and gradually spread to the north of the coast. Then, the protein concentration decreased again in November and December. This monthly pattern of the protein concentration is similar to the Chl-a pattern, which has bimodal peaks that occurred in spring and autumn previously reported in the EJS $[5,7,32]$.

\subsection{Long-Term Variation in MODIS-derived Protein Concentration}

Time series of the monthly averages of MODIS-derived protein concentration of phytoplankton were generated in our study area from January 2003 to December 2019 (Figure 7). The highest protein concentration was $138.2 \mu \mathrm{g} \cdot \mathrm{L}^{-1}$ in April 2008, and the lowest was $26.6 \mu \mathrm{g} \cdot \mathrm{L}^{-1}$ in February 2018. The average of the highest concentration throughout the years was $79.9 \mu \mathrm{g} \cdot \mathrm{L}^{-1}\left( \pm 18.3 \mu \mathrm{g} \cdot \mathrm{L}^{-1}\right)$, whereas the average of the lowest concentration was $32.7 \mu \mathrm{g} \cdot \mathrm{L}^{-1}\left( \pm 4.1 \mu \mathrm{g} \cdot \mathrm{L}^{-1}\right)$ throughout the years. Generally, bimodal peaks were observed every year. The highest peaks were found in the spring seasons (April) and the second peaks occurred in the autumn seasons (September to November). But the highest peaks were in the autumn seasons and the second peaks were in spring seasons in some years (e.g., 2010-2014 and 2016). Otherwise, the lowest protein concentrations were observed in winter or early spring (January to March). The annual protein concentration of phytoplankton was plotted from 2003 to 2019 (Figure 8). The range of the annual protein concentration was $52.3 \mu \mathrm{g} \cdot \mathrm{L}^{-1}$ in 2012 to $66.5 \mu \mathrm{g} \cdot \mathrm{L}^{-1}$ in 2008 with an average of $57.7 \mu \mathrm{g} \cdot \mathrm{L}^{-1}$ $\left(\right.$ S.D. $\left.= \pm 2.9 \mu \mathrm{g} \cdot \mathrm{L}^{-1}\right)$. There was no remarkable trend in the annual protein concentration of phytoplankton in the study area during our observation period. 


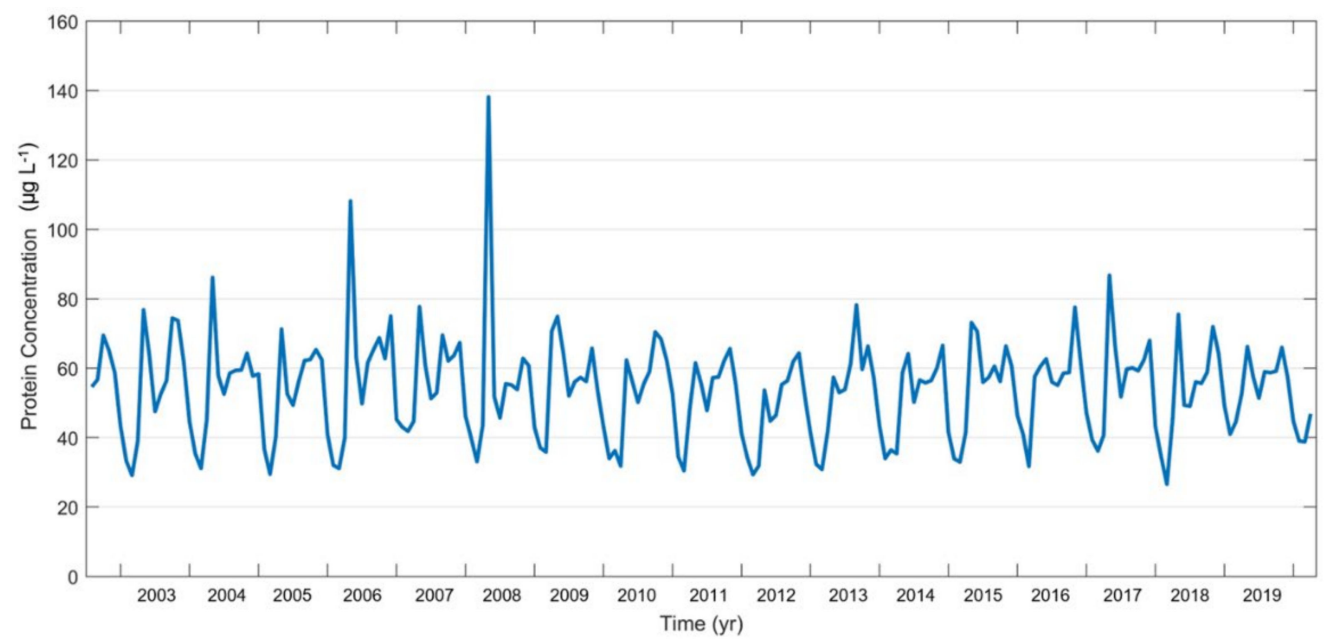

Figure 7. Time-series of monthly mean protein concentration of phytoplankton in East/Japan Sea (EJS) from January 2003 to December 2019.
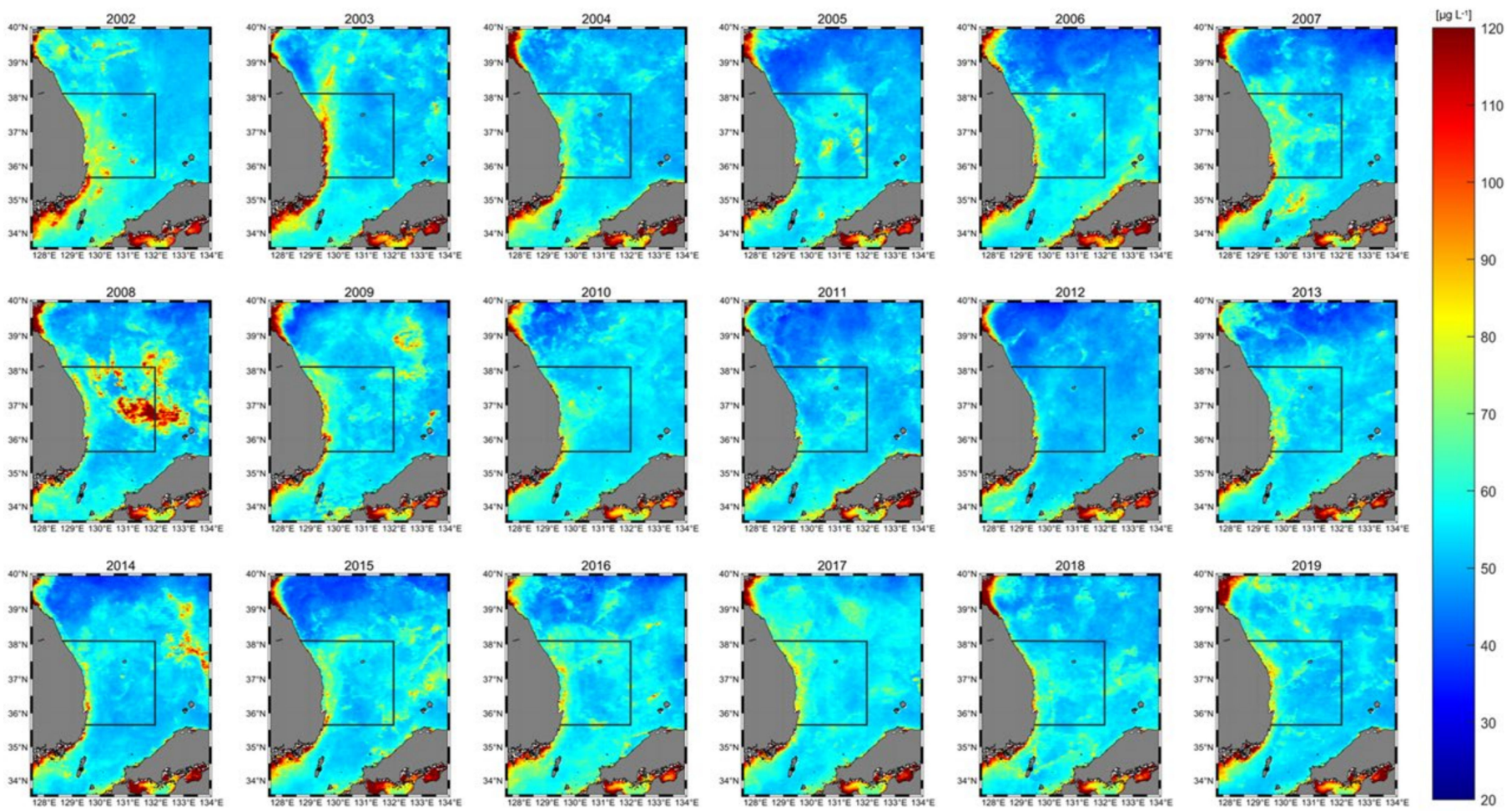

Figure 8. Long-Term pattern of the protein concentration of phytoplankton in the East/Japan Sea (EJS) from 2003 to 2019.

Although no significant trend was found in the annual protein concentration of the phytoplankton, there was a notable difference in the seasonal distribution in protein concentration between the 3-year average of 2003-2005 period and 2017-2019 period (Figure 9). The 2017-2019 period of winter protein concentration $\left(42.4 \pm 1.9 \mu \mathrm{g} \cdot \mathrm{L}^{-1}\right)$ was significantly higher than the 2003-2005 period $\left(34.0 \pm 1.5 \mu \mathrm{g} \cdot \mathrm{L}^{-1}\right)(t$-test, $p<0.01)$. Especially, the protein concentration in February was approximately 20 percent higher than in 2003-2005 period than in 2017-2019 period ( $t$-test, $p<0.01$ ). To find a major controlling factor for the difference in February between the two periods, physicochemical environmental conditions were analyzed with PCA (Table 3). The February protein concentration of phytoplankton was negatively correlated with mixed layer depth $(r$-value $=-0.74, p<0.001, \mathrm{n}=17)$ and SSN $(r$-value $=-0.927, p<0.000, \mathrm{n}=17)$, while positively correlated with SST $(r$-value $=0.85$, $p<0.000, \mathrm{n}=17)$ and Chl-a concentration $(r$-value $=0.88, p<0.000, \mathrm{n}=17)$. 


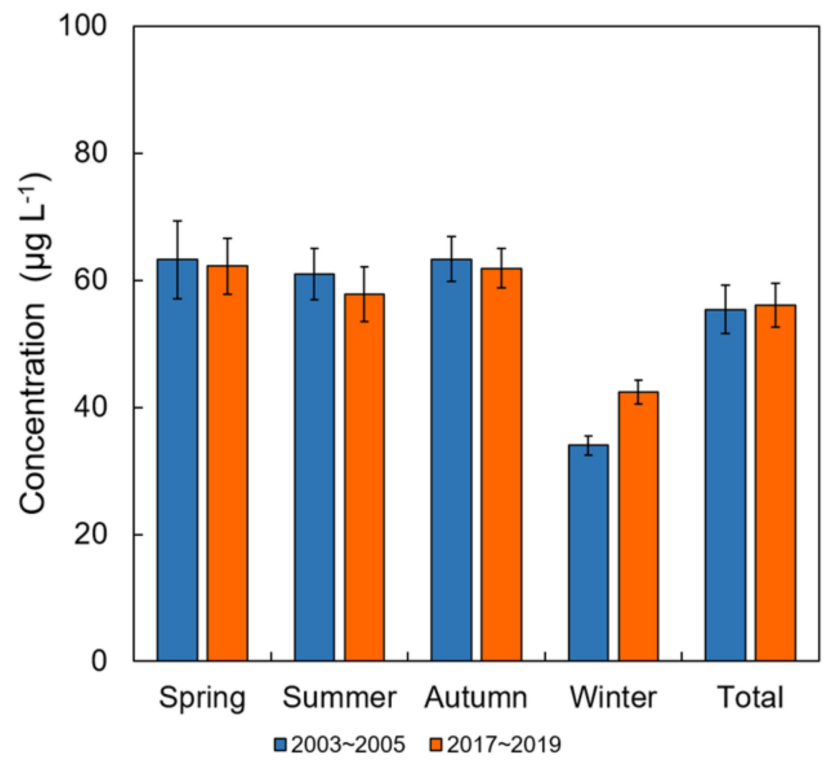

Figure 9. The seasonal distribution between 3 years average of protein concentration 2003-2005 period and 2017-2019 period, which were the oldest and latest data accessible from the MODISAqua satellite.

Table 3. The correlation between the protein concentration of phytoplankton with satellite-derived data of physical, chemical, and biological variables during February.

\begin{tabular}{|c|c|c|c|c|c|}
\hline February $(n=17)$ & PRT & MLD & SSN & SST & Chl-a \\
\hline PRT & 1 & - & - & - & - \\
\hline MLD & $\begin{array}{l}-0.740 \\
0.001 * *\end{array}$ & 1 & - & - & - \\
\hline SSN & $\begin{array}{c}-0.927 \\
0.0000\end{array}$ & $\begin{array}{c}0.650 \\
0.005^{* *}\end{array}$ & 1 & - & - \\
\hline SST & $\begin{array}{c}0.851 \\
0.000 * *\end{array}$ & $\begin{array}{l}-0.576 \\
0.015^{* *}\end{array}$ & $\begin{array}{l}-0.981 \\
0.000^{* *}\end{array}$ & 1 & - \\
\hline Chl-a & $\begin{array}{c}0.877 \\
0.000 * *\end{array}$ & $\begin{array}{l}-0.696 \\
0.002 * *\end{array}$ & $\begin{array}{l}-0.633 \\
0.006^{* *}\end{array}$ & $\begin{array}{c}0.500 \\
0.041 \text { * }\end{array}$ & - \\
\hline
\end{tabular}

PRT = protein concentration of phytoplankton, MLD = mixed layer depth, SSN = sea surface nitrate, SST = sea surface temperature, $\mathrm{Chl}-\mathrm{a}=$ chlorophyll-a; ${ }^{*} p<0.05,{ }^{* *} p<0.01$.

\section{Discussion}

\subsection{Majour Controlling Factors for the Protein Concentration of Phytoplankton}

Multiple linear regression analyses were used to find major environmental factors controlling for the protein concentration of phytoplankton. The principal factors for the protein concentration were identified as Chl-a and SSN concentrations in the southwestern EJS. In other words, the protein concentration of phytoplankton might be considerably influenced by the Chl-a and SSN (Table 2), which are independent variables based on the multilinear regression analysis. The contribution of the Chl-a was larger than SSN, indicating that the Chl-a was a more critical factor for the protein concentration of phytoplankton in EJS. Given the results from the multilinear regression analysis, we expect that the enhanced Chl-a and the consumed SSN induce higher protein concentrations. Conventionally, the Chl-a concentration is strongly associated with the overall trend in the protein concentration of phytoplankton. Smit et al. [12] observed that proteins and Chl-a concentrations have a positive relationship. In addition, nitrogen is the constituent of protein and genetic materials. Nitrate, nitrite, ammonium, and dissolved organic nitrogen are the supplement of nitrogen. Normally, phytoplankton using nitrate as a nitrogen source requires nitrate reductase to synthesize the reduced organic nitrogen-compounds like proteins and amino acids, whereas no needed nitrate reductase for ammonium $[20,33]$. 
Hence, ammonium is preferred to phytoplankton, and thus, ammonium assimilation rate is normally higher than nitrate [34-36]. Ammonium is redistributed through reproduction by phytoplankton, while nitrate which is relatively difficult to supply is depleted and could be a limiting factor to phytoplankton [34]. Accordingly, the nitrate concentrations could influence the concentration of proteins. Under nitrate depletion, phytoplankton growth proceeds slowly and their photosynthetic production is decreased [37,38]. Previous studies have reported that photosynthesis may continue when the supply of nitrate is not sufficient, but the proportion of proteins which are nitrogen-rich components could be decreased whereas the proportions of lipids and carbohydrates which are more energy-rich components could be increased $[39,40]$. Therefore, it can be explained that the result of the algorithm, high Chl-a concentration, and intake of SSN has a great influence on the increase in protein concentration of phytoplankton.

\subsection{The Spatial and Seasonal Variation in Protein Concentration of Phytoplankton in the EJS}

The average MODIS-derived monthly protein concentration $\left(54.1 \pm 14.3 \mu \mathrm{g} \cdot \mathrm{L}^{-1}\right)$ in this study from 2003 to 2019 is somewhat lower compared to the average protein concentrations from Kang et al. [41] who reported $65.5 \mu \mathrm{g} \cdot \mathrm{L}^{-1}\left( \pm 27.1 \mu \mathrm{g} \cdot \mathrm{L}^{-1}\right)$ for fall 2012 and $74.6 \mu \mathrm{g} \cdot \mathrm{L}^{-1}\left( \pm 36.9 \mu \mathrm{g} \cdot \mathrm{L}^{-1}\right)$ for spring 2015 in the northern EJS based on their field measurements. Kang et al. [42] consistently observed similar protein concentrations in the EJS during April $2016\left(71.4 \pm 30.0 \mu \mathrm{g} \cdot \mathrm{L}^{-1}\right)$, as the spring protein concentration in Kang et al. [41]. Protein concentrations of phytoplankton have a seasonal pattern observed in the EJS from the time-series ocean color data from 2003 to 2019. High concentrations of protein were observed in spring and autumn; slightly lower protein concentrations were observed in summer and decreased sharply in winter, which is a typical seasonal distribution of phytoplankton growth along the season depending on environmental conditions [14]. The protein of phytoplankton appears to have high correlations with the growth rate of phytoplankton in the EJS [15]. However, the southwest part of the EJS has always a higher concentration in all seasons except winter. Consistently, relatively higher average protein concentration $\left(85.2 \pm 58.9 \mu \mathrm{g} \cdot \mathrm{L}^{-1}\right)$ was measured in the southwestern EJS based on monthly measurements from April to November 2014 [10]. It might be induced by the coastal upwelling which occurs frequently from spring to autumn as the monsoon wind changes its direction from northwesterly to southwesterly on the east coast of Korea [5]. Coastal upwelling enhances the primary production and the biomass of phytoplankton because of the increased nitrate supply and light ability to phytoplankton in the southwest of the EJS $[4,43,44]$. Hence, the high protein concentration in coastal regions could be influenced by coastal upwelling. Roy [25] reported that globally the protein concentrations in coastal regions were higher than those in open oceans, although the uncertainty remains high.

\subsection{The Low Limit of Protein Concentration of Phytoplankton}

From 2003 to 2019, the average of the lowest protein concentration of each year was $33.3 \mu \mathrm{g} \cdot \mathrm{L}^{-1}\left( \pm 4.69 \mu \mathrm{g} \cdot \mathrm{L}^{-1}\right)$, and the lowest protein concentration was $26.6 \mu \mathrm{g} \cdot \mathrm{L}^{-1}$ in February 2018 (Figure 6). The lowest annual protein concentration was in winter, January and February, except one year (March 2010). In winter, the Asian winter monsoon prevailed with northerly winds in the EJS [5]. The wind stirring and surface cooling due to monsoons and winter convection results in deeper mixed layer depth (MLD) [45]. The deep MLD is a well-mixed condition, which can redistribute major inorganic nutrients to surface water. However, phytoplankton growth is mainly controlled by light availability during the winter season. The weak solar radiation and deep mixed layer in winter contribute to the low Chl-a concentration. Previous studies reported that the synthesis of proteins is relatively maintained under harsh environmental conditions which cause low biomass, production, and growth of phytoplankton $[15,46]$. Particularly in coastal waters, when primary production decreased, the synthesis of macromolecules was reduced, but protein synthesis was reduced less than other macromolecules such as carbohydrates and lipids [46]. 
In general, the conservation of protein synthesis implies that basic cellular functions are sustained in growth-limiting conditions. This pattern is robust and persistent over the entire annual cycle, despite the occurrence of major changes in the species composition of phytoplankton assemblages $[19,46,47]$. Therefore, when the growth conditions are not favorable like in winter, with low light availability, protein concentration is kept at a certain value, approximately $30 \mu \mathrm{g} \cdot \mathrm{L}^{-1}$ in the southwestern EJS.

\subsection{Recent Trend of Protein Concentration of Phytoplankton}

Even if the annual protein concentration has no significant trend from 2003 to 2019, the average protein concentration for recent 3 years (2017-2019) in winter, specifically February, was 20 percent higher compared to that in the former period (2003-2005) (Figure 9). Generally, the lowest protein concentrations were in February of each year, except 2010 (March) and 2014 and 2019 (January). There might be some reasons for the increasing rates of protein concentration. A possible reason would the increase of SST in the EJS which has experienced a warming trend over recent decades according to previous reports $[48,49]$. The warming SST could lead to increase surface water stratification and consequently decrease the influx of major inorganic nutrients into the upper euphotic layer. Toseland et al. [50] found that SST affects the core metabolism of phytoplankton such as protein synthesis and RNA. Increasing SST can cause changes in phytoplankton physiological states to a high N:P ratio in phytoplankton cellular [50] and thus increase the protein synthesis rate. Indeed, the SST in February during the recent period (2017-2019) was higher $\left(0.8^{\circ} \mathrm{C}\right)$ than that during the former period (2003-2005). In this study, we found the protein concentration was strongly positively correlated with the SST during February (Table 3). Another possible reason could be MLD. MLD controls the availability of nutrients and lights to phytoplankton in the upper ocean [51,52]. The maximum MLD appears during the wintertime from November to March, especially February in this study period. In particular, winter mixing is essential to the water formation that determines the property of the thermocline water and connects the upper ocean to the deep ocean [53]. According to previous reports, the MLD has been decreased by reduced surface cooling and weaken wind stress in the EJS $[45,54]$, which could affect the biomass, biochemical compositions, and primary production of phytoplankton. This study was found a negative correlation between MLD and protein concentration of phytoplankton in February (Table 3). The shallower MLD matched with an elevated protein concentration of phytoplankton in this study. Therefore, the increase in protein concentration of phytoplankton in winter is a result of a well-growing environment for phytoplankton by increased water temperature and shallowed MLD.

\section{Summary and Conclusions}

In this study, we estimated the protein concentration of phytoplankton using the regional algorithm from MODIS-derived ocean color data and determined the temporal and spatial variation of the protein concentration in the EJS from 2003 to 2019. Two environmental parameters (SST and Chl-a) were selected as major factors for the algorithm of phytoplankton protein concentration based on in situ data. The algorithm-derived estimation from MODIS-aqua retrieved-data and the field-measured data generally follow the 1:1 line, with a significant Pearson's correlation coefficient which was 0.40 and the $p$-value was $<0.01$ with $n=135$. Based on the results, the monthly mean protein concentration of phytoplankton showed a strong seasonality in the EJS. The seasonal variation of protein concentrations has bimodal peaks that occurred in spring and autumn. Interestingly, the protein concentration has a low limit of approximately $30 \mu \mathrm{g} \cdot \mathrm{L}^{-1}$ in the southwestern EJS since the protein synthesis is maintained in harsh conditions such as low phytoplankton biomass, production, and growth. The average annual protein concentration had no specific trend in the EJS over the observation period from 2003 to 2019. The winter protein concentration of phytoplankton was higher than before. This suggests that the protein concentration of phytoplankton in winter is more sensitive toward ongoing 
warming trends like increasing SST and shallowing MLD in the EJS. Approximately $55 \%$ of the prediction for the protein concentration of phytoplankton were obtained in this study based on surface Chl-a concentration and SSN in the EJS, which suggests that other parameters are needed to improve our algorithm. For example, the protein concentrations of phytoplankton could be strongly associated with size-specific Chl-a contributions. Indeed, higher protein concentrations were found in large-sized cells of phytoplankton compared to small cells in the EJS [42]. Therefore, different size compositions of phytoplankton rather than total Chl-a concentration should be considered for improving the algorithm derived in this study. Moreover, the lack of seasonal data in the EJS in December and January could be one of the potential reasons causing the bias and uncertainties of our algorithm although field-measured data for the protein concentrations from various cruises (Table 1) were used for this study. Other algorithms for carbohydrate and lipid concentrations of phytoplankton are highly recommended to understand the potential influence of global warming on the environmental conditions and consequently on phytoplankton ecology and thus the marine ecosystem in the EJS.

Author Contributions: Conceptualization, H.B. and S.-H.L.; methodology, H.B. and D.L.; validation, H.B. and D.L.; investigation, D.L., J.J.K., J.H.L., N.J., K.K., H.K.J., M.J.K. and Y.K.; data curation, H.B., D.L., J.J.K., J.H.L., N.J., K.K., H.K.J., M.J.K. and Y.K.; writing—original draft preparation, H.B.; writing - review and editing, S.H.L.; visualization, H.B.; supervision, S.H.L.; project administration, J.-I.K. and S.H.L.; funding acquisition, J.-I.K. and S.H.L. All authors have read and agreed to the published version of the manuscript.

Funding: This research was supported by "Long-term change of structure and function in marine ecosystems of Korea" and "Improvements of ocean prediction accuracy using numerical modeling and artificial intelligence technology" funded by the Ministry of Oceans and Fisheries, Republic of Korea.

Institutional Review Board Statement: Not applicable.

Informed Consent Statement: Not applicable.

Data Availability Statement: Not applicable.

Acknowledgments: The authors would like to thank the anonymous reviewers and the handling editors who dedicated their time to providing the authors with constructive and valuable recommendations.

Conflicts of Interest: The authors declare no conflict of interest.

\section{References}

1. Kang, Y.S.; Kim, J.Y.; Kim, H.G.; Park, J.H. Long-term changes in zooplankton and its relationship with squid, Todarodes pacificus, catch in Japan/East Sea. Fish. Oceanogr. 2002, 11, 337-346. [CrossRef]

2. Kim, D.; Yang, E.J.; Kim, K.H.; Shin, C.-W.; Park, J.; Yoo, S.; Hyun, J.-H. Impact of an anticyclonic eddy on the summer nutrient and chlorophyll a distributions in the Ulleung Basin, East Sea (Japan Sea). ICES J. Mar. Sci. 2012, 69, 23-29. [CrossRef]

3. Lim, J.-H.; Son, S.; Park, J.-W.; Kwak, J.H.; Kang, C.-K.; Son, Y.B.; Kwon, J.-N.; Lee, S.H. Enhanced biological activity by an anticyclonic warm eddy during early spring in the East Sea (Japan Sea) detected by the geostationary ocean color satellite. Ocean Sci. J. 2012, 47, 377-385. [CrossRef]

4. Joo, H.T.; Park, J.W.; Son, S.H.; Noh, J.-H.; Jeong, J.-Y.; Kwak, J.H.; Saux-Picart, S.; Choi, J.H.; Kang, C.-K.; Lee, S.H. Long-term annual primary production in the Ulleung Basin as a biological hot spot in the East/Japan Sea. J. Geophys. Res. Ocean. 2014, 119, 3002-3011. [CrossRef]

5. Chang, K.-I.; Zhang, C.-I.; Park, C.; Kang, D.-J.; Ju, S.-J.; Lee, S.-H.; Wimbush, M. (Eds.) Oceanography of the East Sea (Japan Sea); Springer International Publishing: Cham, Switzerland, 2016; ISBN 978-3-319-22719-1.

6. Chiba, S.; Toshiro, S. Interdecadal change in the upper water column environment and spring diatom community structure in the Japan Sea: An early summer hypothesis. Mar. Ecol. Prog. Ser. 2012, 231, 23-35. [CrossRef]

7. Lee, S.H.; Son, S.; Dahms, H.-U.; Park, J.W.; Lim, J.-H.; Noh, J.-H.; Kwon, J.-I.; Joo, H.T.; Jeong, J.Y.; Kang, C.-K. Decadal changes of phytoplankton chlorophyll-a in the East Sea/Sea of Japan. Oceanology 2014, 54, 771-779. [CrossRef]

8. Geider, R.J.; Moore, C.M.; Ross, O.N. The role of cost-benefit analysis in models of phytoplankton growth and acclimation. Plant. Ecol. Divers. 2009, 2, 165-178. [CrossRef]

9. Yamada, K.; Ishizaka, J.; Yoo, S.; Kim, H.-c.; Chiba, S. Seasonal and interannual variability of sea surface chlorophyll a concentration in the Japan/East Sea (JES). Prog. Oceanogr. 2004, 61, 193-211. [CrossRef] 
10. Jo, N.; Kang, J.J.; Park, W.G.; Lee, B.R.; Yun, M.S.; Lee, J.H.; Kim, S.M.; Lee, D.; Joo, H.T.; Lee, J.H.; et al. Seasonal variation in the biochemical compositions of phytoplankton and zooplankton communities in the southwestern East/Japan Sea. Deep Sea Res. Part II Top. Stud. Oceanogr. 2017, 143, 82-90. [CrossRef]

11. Jung, H.K.; Rahman, M.S.; Kang, C.-K.; Park, S.-Y.; Lee, S.H.; Park, H.J.; Kim, H.-W.; Lee, C.I. The influence of climate regime shifts on the marine environment and ecosystems in the East Asian Marginal Seas and their mechanisms. Deep Sea Res. Part II Top. Stud. Oceanogr. 2017, 143, 110-120. [CrossRef]

12. Smit, A.J.; Robertson, B.L.; Preez, D.R. Influence of ammonium-N pulse concentrations and frequency, tank condition and nitrogen starvation on growth rate and biochemical composition of Gracilaria gracilis. J. Appl. Phycol. 1996, 8, 473-481. [CrossRef]

13. Litzow, M.A.; Bailey, K.M.; Prahl, F.G.; Heintz, R. Climate regime shifts and reorganization of fish communities: The essential fatty acid limitation hypothesis. Mar. Ecol. Prog. Ser. 2006, 315, 1-11. [CrossRef]

14. DiTullio, G.R.; Laws, E.A. Estimates of phytoplankton N uptake based on 14CO2 incorporation into protein. Limnol. Oceanogr. 1983, 28, 177-185. [CrossRef]

15. Lee, S.H.; Kim, H.-J.; Whitledge, T.E. High incorporation of carbon into proteins by the phytoplankton of the Bering Strait and Chukchi Sea. Cont. Shelf Res. 2009, 29, 1689-1696. [CrossRef]

16. Geider, R.J.; MacIntyre, H.L.; Kana, T.M. A dynamic model of photoadaptation in phytoplankton. Limnol. Oceanogr. 1996, 41, 1-15. [CrossRef]

17. Marañón, E.; Fernández, E.; Anadón, R. Patterns of macromolecular synthesis by natural phytoplankton assemblages under changing upwelling regimes: In situ observations and microcosm experiments. J. Exp. Mar. Biol. Ecol. 1995, 88, 1-28. [CrossRef]

18. Marañón, E.; González, N. Primary production, calcification and macromolecular synthesis in a bloom of the coccolithophore Emiliania huxleyi in the North Sea. Mar. Ecol. Prog. Ser. 1997, 157, 61-77. [CrossRef]

19. Morris, I. Photosynthetic products, physiological state, and phytoplankton growth. Can. B Fish. Aquat. Sci. 1981, $210,83-102$.

20. Graham, L.; Graham, J.; Wilcox, L. Algae, 2nd ed.; Pearson Education Inc.: San Francisco, CA, USA, 2009 ; pp. 33-34.

21. Reynolds, R.; Stramski, D.; Wright, V.; Woźniak, S. Measurements and characterization of particle size distributions in coastal waters. J. Geophys. Res. Ocean. 2010, 115, C08024. [CrossRef]

22. Vymazal, J. Algae and Element Cycling in Wetlands; Lewis Publishers Inc.: Boca Raton, FL, USA, 1995.

23. Scott, J. Effect of growth rate of the food alga on the growth/ingestion efficiency of a marine herbivore. J. Mar. Biol. Assoc. UK 1980, 60, 681-702. [CrossRef]

24. Lindqvist, K.; Lignell, R. Intracellular partitioning of $14 \mathrm{CO} 2$ in phytoplankton during a growth season in the northern Baltic. Mar. Ecol. Prog. Ser. 1997, 152, 41-50. [CrossRef]

25. Roy, S. Distributions of Phytoplankton Carbohydrate, Protein and Lipid in the World Oceans from Satellite Ocean Colour. ISME J. 2018, 12, 1457-1472. [CrossRef]

26. IOCCG. Phytoplankton Functional Types from Space. In Reports of the International Ocean-Colour Coordinating Group (IOCCG); No 15; Sathyendranath, S., Ed.; International Ocean-Colour Coordinating Group (IOCCG): Dartmouth, NS, USA, 2014.

27. Mouw, C.B.; Hardman-Mountford, N.J.; Alvain, S.; Bracher, A.; Brewin, R.J.; Bricaud, A. A consumer's guide to satellite remote sensing of multiple phytoplankton groups in the global ocean. Front. Mar. Sci. 2017, 4, 41. [CrossRef]

28. Lowry, O.H.; Rosebrough, N.J.; Farr, A.L.; Randall, R.J. Protein measurement with the Folin phenol reagent. J. Biol. Chem. 1951, 193, 265-275. [CrossRef]

29. Bhavya, P.; Kim, B.K.; Jo, N.; Kim, K.; Kang, J.J.; Lee, J.H.; Ahn, S.H. A review on the macromolecular compositions of phytoplankton and the implications for aquatic biogeochemistry. Ocean Sci. J. 2019, 54, 1-14. [CrossRef]

30. Joo, H.; Lee, D.; Son, S.H.; Lee, S.H. Annual New Production of Phytoplankton Estimated from MODIS-Derived Nitrate Concentration in the East/Japan Sea. Remote Sens. 2018, 10, 806. [CrossRef]

31. Werdell, P.J.; Bailey, S.W.; Franz, B.A.; Harding, L.W., Jr.; Feldman, G.C.; McClain, C.R. Regional and seasonal variability of chlorophyll-a in Chesapeake Bay as observed by SeaWiFS and MODIS-Aqua. Remote Sens. Environ. 2009, 113, 1319-1330. [CrossRef]

32. Zuenko, Y.; Selina, M.; Stonik, I. On conditions of phytoplankton blooms in the coastal waters of the north-western East/Japan Sea. Ocean Sci. J. 2006, 41, 31-41. [CrossRef]

33. McCarthy, J.J.; Taylor, W.R.; Taft, J.L. Nitrogenous nutrition of the plankton in the Chesapeake Bay. 1. Nutrient availability and phytoplankton preferences. Limnol. Oceanogr. 1977, 22, 996-1011. [CrossRef]

34. McCarthy, J.J.; Wynne, D.; Berman, T. The uptake of dissolved nitrogen? Us nutrients by Lake Kinneret (Israel) microplanktorP. Limnol. Oceanogr. 1982, 27, 673-680. [CrossRef]

35. Dortch, Q.; Postel, J.R. During upwelling off the Biochemical indicators of N utilization by phytoplankton Washington coast. Limnol. Oceanogr. 1989, 34, 758-773. [CrossRef]

36. Mallet, C.; Charpin, M.; Devaux, J. Nitrate reductase activity of phytoplankton populations in eutrophic Lake Aydat and meso-oligotrophic Lake Pavin: A comparison. In Oceans, Rivers and Lakes: Energy and Substance Transfers at Interfaces; Amiard, J.-C., Le Rouzic, B., Berthet, B., Bertru, G., Eds.; Amazon: Nantes, France, 1998; pp. 135-148.

37. Chen, C.-Y.; Yeh, K.-L.; Aisyah, R.; Lee, D.-J.; Chang, J.-S. Cultivation, photobioreactor design and harvesting of microalgae for biodiesel production: A critical review. Bioresour. Technol. 2011, 102, 71-81. [CrossRef]

38. Bona, F.; Capuzzo, A.; Franchino, M.; Maffei, M.E. Semicontinuous nitrogen limitation as convenient operation strategy to maximize fatty acid production in Neochloris oleoabundans. Algal Res. 2014, 5, 1-6. [CrossRef] 
39. Jiang, Y.; Yoshida, T.; Quigg, A. Photosynthetic performance, lipid production and biomass composition in response to nitrogen limitation in marine microalgae. Plant Physiol. Biochem. 2012, 54, 70-77. [CrossRef]

40. Klok, A.J.; Martens, D.E.; Wijffels, R.H.; Lamers, P.P. Simultaneous growth and neutral lipid accumulation in microalgae. Bioresour. Technol. 2013, 134, 233-243. [CrossRef] [PubMed]

41. Kang, J.J.; Joo, H.; Lee, J.H.; Lee, J.H.; Lee, H.W.; Lee, D. Comparison of biochemical compositions of phytoplankton during spring and fall seasons in the northern East/Japan Sea. Deep Sea Res. Part II 2017, 143, 73-81. [CrossRef]

42. Kang, J.J.; Jang, H.K.; Lim, J.-H.; Lee, D.; Lee, J.H.; Bae, H. Characteristics of Different Size Phytoplankton for Primary Production and Biochemical Compositions in the Western East/Japan Sea. Front. Microbiol. 2020, 11, 3306. [CrossRef] [PubMed]

43. Onitsuka, G.; Yanagi, T.; Yoon, J.H. A numerical study on nutrient sources in the surface layer of the Japan Sea using a coupled physical-ecosystem model. J. Geophys. Res. Ocean. 2007, 112, C05042. [CrossRef]

44. Yoo, S.; Park, J. Why is the southwest the most productive region of the East Sea/Sea of Japan? J. Mar. Syst. 2009, 78, 301-315. [CrossRef]

45. Lim, S.; Jang, C.J.; Oh, I.S.; Park, J. Climatology of the mixed layer depth in the East/Japan Sea. J. Mar. Syst. 2012, 96-97, 1-14. [CrossRef]

46. Suárez, I.; Marañón, E. Photosynthate allocation in a temperate sea over an annual cycle: The relationship between protein synthesis and phytoplankton physiological state. J. Sea Res. 2005, 50, 285-299. [CrossRef]

47. Halsey, K.H.; Jones, B.M. Phytoplankton strategies for photosynthetic energy allocation. Annu. Rev. Mar. Sci. 2015, 7, $265-297$. [CrossRef]

48. Kim, K.; Kim, K.R.; Min, D.H.; Volkov, Y.; Yoon, J.H.; Takematsu, M. Warming and structural changes in the East (Japan) Sea: A clue to future changes in global oceans? Geophys. Res. Lett. 2001, 28, 3293-3296. [CrossRef]

49. Jo, C.O.; Park, S.; Kim, Y.H.; Park, K.-A.; Park, J.J.; Park, M.-K.; Kim, K.-R. Spatial distribution of seasonality of SeaWiFS chlorophyll-a concentrations in the East/Japan Sea. J. Mar. Syst. 2014, 139, 288-298. [CrossRef]

50. Toseland, A.; Daines, S.J.; Clark, J.R.; Kirkham, A.; Strauss, J.; Uhlig, C.; Leton, T.M.; Valentin, K.; Pearson, G.A.; Moulton, V.; et al. The impact of temperature on marine phytoplankton resource allocation and metabolism. Nat. Clim. Chang. 2013, 3, 979-984. [CrossRef]

51. Sverdrup, H. On conditions for the vernal blooming of phytoplankton. Cons. Int. Explor. Mer. 1953, 18, 287-295. [CrossRef]

52. Yentsch, C. Estimates of 'new production' in the Mid-North Atlantic. J. Plankton Res. 1990, 12, 717-734. [CrossRef]

53. Hanawa, K.; Talley, L.D. Mode waters. Int. Geophys. Ser. 2001, 77, 373-386.

54. Chang, P.-H.; Cho, C.-H.; Ryoo, S.-B. Recent changes of Mixed Layer Depth in the East/Japan Sea: 1994-2007. Asia Pac. J. Atmos. Sci. 2011, 47, 497-501. [CrossRef] 